\title{
Climate-driven disturbances in the San Juan River sub-basin of the Colorado River
}

\author{
Katrina E. Bennett ${ }^{1}$, Theodore J. Bohn ${ }^{2,3}$, Kurt Solander ${ }^{1}$, Nathan G. McDowell ${ }^{1, a}$, Chonggang Xu ${ }^{1}$, \\ Enrique Vivoni $^{3,4}$, and Richard S. Middleton ${ }^{1}$ \\ ${ }^{1}$ Earth and Environmental Sciences, Los Alamos National Lab, Los Alamos, NM 87545, USA \\ ${ }^{2}$ Julie Ann Wrigley Global Institute of Sustainability, Arizona State University, Tempe, AZ 85287, USA \\ ${ }^{3}$ School of Earth and Space Exploration, Arizona State University, Tempe, AZ 85287, USA \\ ${ }^{4}$ School of Sustainable Engineering and the Built Environment, Arizona State University, Tempe, AZ 85287, USA \\ ${ }^{a}$ current address: Pacific Northwest National Laboratory, Richland, WA 99354, USA
}

Correspondence: Katrina E. Bennett (kbennett@lanl.gov)

Received: 5 April 2017 - Discussion started: 24 April 2017

Revised: 1 November 2017 - Accepted: 8 December 2017 - Published: 26 January 2018

\begin{abstract}
Accelerated climate change and associated forest disturbances in the southwestern USA are anticipated to have substantial impacts on regional water resources. Few studies have quantified the impact of both climate change and land cover disturbances on water balances on the basin scale, and none on the regional scale. In this work, we evaluate the impacts of forest disturbances and climate change on a headwater basin to the Colorado River, the San Juan River watershed, using a robustly calibrated (Nash-Sutcliffe efficiency 0.76 ) hydrologic model run with updated formulations that improve estimates of evapotranspiration for semiarid regions. Our results show that future disturbances will have a substantial impact on streamflow with implications for water resource management. Our findings are in contradiction with conventional thinking that forest disturbances reduce evapotranspiration and increase streamflow. In this study, annual average regional streamflow under the coupled climate-disturbance scenarios is at least $6-11 \%$ lower than those scenarios accounting for climate change alone; for forested zones of the San Juan River basin, streamflow is $15-21 \%$ lower. The monthly signals of altered streamflow point to an emergent streamflow pattern related to changes in forests of the disturbed systems. Exacerbated reductions of mean and low flows under disturbance scenarios indicate a high risk of low water availability for forested headwater systems of the Colorado River basin. These findings also indicate that explicit representation of land cover disturbances
\end{abstract}

is required in modeling efforts that consider the impact of climate change on water resources.

\section{Introduction}

Widespread forest disturbances are projected to increase with climate change (McDowell et al., 2016; Allen et al., 2010; Van Mantgem et al., 2009) and this will have major implications for ecosystem services (Anderegg et al., 2013). These ecosystem services impact the provision of food, water, and energy and therefore necessitate a more robust understanding of (a) how the landscape will respond to the associated shifts in timing and frequency of streamflow and (b) the dominant processes driving these changes. However, the impacts of coupled disturbances (e.g., climate-induced pest outbreaks, fires, drought) in forest ecosystems on water resources remain understudied, despite its importance for natural resource management and energy production in affected basins around the globe. For instance, climate-induced changes in forests will feedback to the climate system by altering the albedo and reducing the carbon sink, which is anticipated to further transform ecosystems in either positive or negative ways (Dale et al., 2001). This is particularly salient for regions of the USA such as the Colorado River basin (CRB), where forest cover is anticipated to be significantly impacted by a higher incidence of wildfire, drought, and pest infestations (Williams et al., 2013). 
To date, predictions of future streamflow in forested river basins under future changes in climate and land cover have exhibited wide disagreement as to the strength and even the direction of change. Water yields and peak streamflows in North American river basins are anticipated to either increase, decrease, or show no response to changing forest cover (see Table 2 in Adams et al., 2012; Schnorbus et al., 2010; Guardiola-Claramonte et al., 2011; Somor, 2010; McDowell et al., 2018). Causes of the reported changes have been related to topography (Schnorbus et al., 2010) and climate variability (Allen et al., 2015). Other reported causes are secondary impacts occurring as a result of forest mortality that enhance processes such as radiation (Royer et al., 2011; Varhola et al., 2010), changes in albedo (Winkler et al., 2010), evapotranspiration (Zou et al., 2010; Kang et al., 2006), groundwater availability (Bearup et al., 2014, 2016), and soil moisture states (Dale et al., 2001). Snow has been reported to play an important role in changes in streamflow (Solander et al., 2017; Bennett et al., 2015) through increased snow accumulation and snowmelt (Bewley et al., 2010; Boon, 2007), snow cover duration (Boon, 2009), reduced interception, canopy sublimation, and evapotranspiration in disturbed forests (Livneh et al., 2015b). Temperature changes were noted to play a role in decreasing streamflow in one of eight catchments examined in Somor (2010). Some research points to the fact that we have a limited understanding on why or how streamflow changes in the future under land cover shifts (Bonan, 2008; Buma and Livneh, 2015, 2017).

Disturbances inducing forest loss are poorly represented or entirely absent from earth system models (ESMs) and eco-hydrologic models (Brovkin et al., 2013a; Scheller and Mladenoff, 2007; McDowell et al., 2011). In the Coupled Model Intercomparison Project phase 5 (CMIP5), several ESMs contain dynamic vegetation models (Collins et al., 2011; Watanabe et al., 2011; Brovkin et al., 2013b). ESMs in CMIP5 model fractional plant functional types (PFTs) and include feedbacks to the climate and land surface driven by atmospheric simulations. However, in general, ESMs contain simplifications of the explicit scenario of evolving landscape ecology and do not include a full suite of disturbances (e.g., pests, drought, wildfire), which are extremely difficult to simulate due to the computational expense associated with the coupling between disturbances and the disparate timescales involved. Therefore, current ESMs are limited in their assessment of the feedbacks driven by the disturbances and the threat of complete system crash, e.g., the loss of large tracts of forests and/or strongly declining water resources (McDowell et al., 2018).

Climate impact studies from the southwestern USA highlight the strong influence of changing temperature and precipitation on forest distributions (Dale et al., 2001), forest mortality (Allen et al., 2015), and streamflow (McCabe and Wolock, 2007; Nash and Gleick, 1991). Specifically, the strong interaction between forests and water (Anderson et al., 1976) means that forest disturbances will have a large im- pact on water volume and the timing of streamflow. Streamflow decreases were previously reported for the upper CRB at Lee's Ferry using the Variable Infiltration Capacity (VIC) hydrologic model (Liang et al., 1994, 1996) forced with future climate change scenarios alone and reported decreased future projected streamflow (Christensen and Lettenmaier, 2002). A separate study reported that the CRB streamflow is highly sensitive to precipitation and temperature shifts, with large reductions in streamflow estimated for small increases in precipitation and temperature (Nash and Gleick, 1991) resulting from enhanced rates of evapotranspiration.

The strong link between forests and water, coupled with the emerging threat to future forest viability and integrity, provides a major impetus to study the combined effects of climate and land cover change on streamflow in the CRB. To this end, we apply a hydrologic model that incorporates projected climate changes as well as forest and land cover changes based on recent research. Unlike many other studies, we have included the impact of regrowth of shrubs into our modeling approach since this is the most likely outcome in the CRB (Rother et al., 2015). We determine the direction and shift in streamflow under different scenarios of climate and land cover changes, and we also identify the physical alterations occurring within watersheds across scales and forest compositions to reveal the driving mechanisms behind the streamflow changes. Knowledge of the physical mechanisms and dominant triggers for streamflow alterations is critical because it will allow decision makers to make moreinformed assessments of near- and long-term water operations in a water-constrained world with a changing climate (Zou et al., 2010).

This paper is arranged as follows: Sect. 2 details information on forest disturbances and the impact of climate change on streamflow, Sect. 3 outlines our study site and methodology, and Sects. 4, 5, and 6 provide results, discussion, and conclusions, respectively.

\section{Climate-driven forest disturbances and climate change impacts on streamflow}

As fire, pests, and drought modify forests in response to climate change, a number of important energy and water fluxes become altered (Adams et al., 2012). Land covers with a low canopy profile and a small crown cover, e.g., shrubs or bare ground, partition water and energy in different manners compared to forests that have a large crown cover. For example, shrubs retain snow pack later into the melt season thus snow is able to reach the ground and accumulate (Boon, 2007, 2009). This is largely due to reduced canopy cover which results in reduced interception and sublimation or transpiration (Pomeroy et al., 1998; Bearup et al., 2014) from this above-ground storage reservoir, as well as higher solar radiation and wind speeds through the open areas (Harpold et al., 2014). Snow also melts quicker in response to increased 
shortwave radiation and turbulent heat transfers linked to negative longwave radiative fluxes (Burles and Boon, 2011). The responses have also been linked to decreased albedo due to higher litter and/or darker soils associated with dying trees (Bewley et al., 2010; Winkler et al., 2010). Other effects of tree mortality on the water balance include changes to soil moisture states, changes in groundwater recharge (Bearup et al., 2016), and potential feedbacks to the atmosphere (Bonan, 2008).

Variations in the type and magnitude of forest disturbances can also strengthen or dampen some of these effects (Buma and Livneh, 2015). For example, forest wildfires change soil properties and litter depths, which in turn alter infiltration and runoff processes. In addition, mountain-pine-beetle infestations change canopy conditions but do not change soil properties or moisture states. Drought may affect the forest canopy and the ability of soils to infiltrate water as trees die and soils desiccate (Adams et al., 2012). Effects may also be impacted by the type of post-disturbance regrowth and extent of disturbance that occurs, such as increases or a difference in shrubs, grasses, forbs coverage, or differences in the composition of tree species that replace the forests (Buma and Livneh, 2017). For instance, water-yield declines have been associated with changes in species compositions of forests in the southern Appalachian Mountains (Caldwell et al., 2016). A recent study indicates that soil water residence time is a key factor in water availability post-disturbance owing to limited (or enhanced) evapotranspiration processes (Buma and Livneh, 2017).

Selection of the appropriate timescale is an important aspect to consider in vegetation disturbance studies. For example, research focused on forest disturbance over a single summer season, such as post-fire hydrology in New Mexico shows that surface runoff and recharge both rise following fire (Atchley et al., 2018). However, these studies do not measure the year-long change in water balance, which is critical for snow-driven systems. Examination of water partitioning in disturbed forests within time frames of less than 5 years may not adequately resolve effects such as forest succession on the hydrologic regime of study basins (Brown et al., 2005), which can result in a significant overestimation of the impacts of changing forests on water yields over the long term (Pugh and Gordon, 2013). Indeed, most studies that encompass forest disturbance monitoring of greater than 5 years point to increased evapotranspiration from understory regrowth and an associated decline or mitigating effect of the forest cover removal (Brown et al., 2014; Biederman et al., 2014; Guardiola-Claramonte et al., 2011). Other research has shown that vegetation management, such as cutting or thinning of forests in the face of climate change, could be used to ameliorate the impacts of reduced streamflow in the CRB, noting that these effects would only last for a period of approximately 10 years (Zou et al., 2010).

Finally, spatial heterogeneity also plays an important role in terms of changing hydro-ecology in the wake of distur- bances. Studies that focus on plot-scale results, where the disturbed forest is the primary cover type, illustrate different responses compared to locations where impacted trees are only a component of the overall land cover, including grasses, shrubs, and non-impacted tree species (Biederman et al., 2014; Pugh and Gordon, 2013). Recent studies examining climate change and extreme wildfire on runoff erosion found that peak streamflow sediment yield will increase with climate change and fire severity due to the lack of spatial heterogeneity in land cover types (Gould et al., 2016). A study by Penn et al. (2016) compared hillslope to watershed-scale responses and found a muted effect on the watershed scale in a headwater basin of the Colorado Rocky Mountains.

\section{Methods}

\subsection{Study site}

To understand the impact of forest disturbances on streamflow under climate changes, on different temporal scales and spatial settings, we implemented the VIC model for the San Juan River basin, a sub-basin of the CRB, to simulate streamflow responses to future changes in temperature, precipitation, and land cover. The San Juan is a major headwater basin of the CRB, accounting for $15 \%$ of streamflow and $22 \%$ of the area of the upper CRB. Spanning four states - the Four Corners - the San Juan watershed is also critical for thermoelectric and hydropower generation, substantial oil and gas development, and extensive irrigated agriculture. Temperature ranges from -2 to $23{ }^{\circ} \mathrm{C}$ from January to July, respectively, while average annual precipitation is $\sim 666 \mathrm{~mm}$. The San Juan basin captures the diversity present across the CRB. For instance, high-elevation ( $>4000 \mathrm{~m}$ ) Colorado mountain ranges and large snowmelt-driven rivers comprise the upper San Juan basin. The lower San Juan basin, located in New Mexico and Arizona, is flat, semi-arid, and representative of the lower CRB, with intermittent streams that drain into the main tributary of the San Juan during the summer when they are charged by summer monsoonal rains. The San Juan River eventually drains into the CRB, just below the town of Bluff, Utah (Fig. 1).

\subsection{Hydrologic model}

For this work, we used the Variable Infiltration Capacity (VIC) model version 4.2 (Bohn and Vivoni, 2016; Liang et al., 1994) at a $1 / 16^{\circ}(6 \mathrm{~km})$ spatial resolution. In each grid cell, VIC simulates vertical energy and water dynamics at a $1 \mathrm{~h}$ time step for a mosaic of land cover tiles underlain by a 3-layer soil column. Sub-grid heterogeneity in infiltration is represented by a statistical distribution (the variable infiltration capacity curve). Surface runoff is generated via saturation excess, while sub-surface runoff is characterized by the non-linear baseflow curve of Franchini and Pacciani (1991). VIC version 4.2 includes fractional canopy coverage derived 
Table 1. Calibration, validation, and entire period of record monthly statistics for simulated to naturalized streamflow for the San Juan at Archuleta, NM, and San Juan at Bluff, UT.

\begin{tabular}{llcc}
\hline & Objective function & San Juan at Archuleta, NM & San Juan at Bluff, UT \\
\hline Calibration (2006-2010) & volume bias & 0.91 & 0.90 \\
& Nash-Sutcliffe efficiency & 0.78 & 0.76 \\
& Nash-Sutcliffe efficiency log & 0.77 & 0.75 \\
\hline Validation (2001-2005) & volume bias & 0.93 & 0.93 \\
& Nash-Sutcliffe efficiency & 0.83 & 0.60 \\
& Nash-Sutcliffe efficiency log & 0.77 & 0.43 \\
\hline Entire period (2001-2010) & volume bias & 0.90 & 0.91 \\
& Nash-Sutcliffe efficiency & 0.81 & 0.67 \\
& Nash-Sutcliffe efficiency log & 0.78 & 0.58 \\
\hline
\end{tabular}

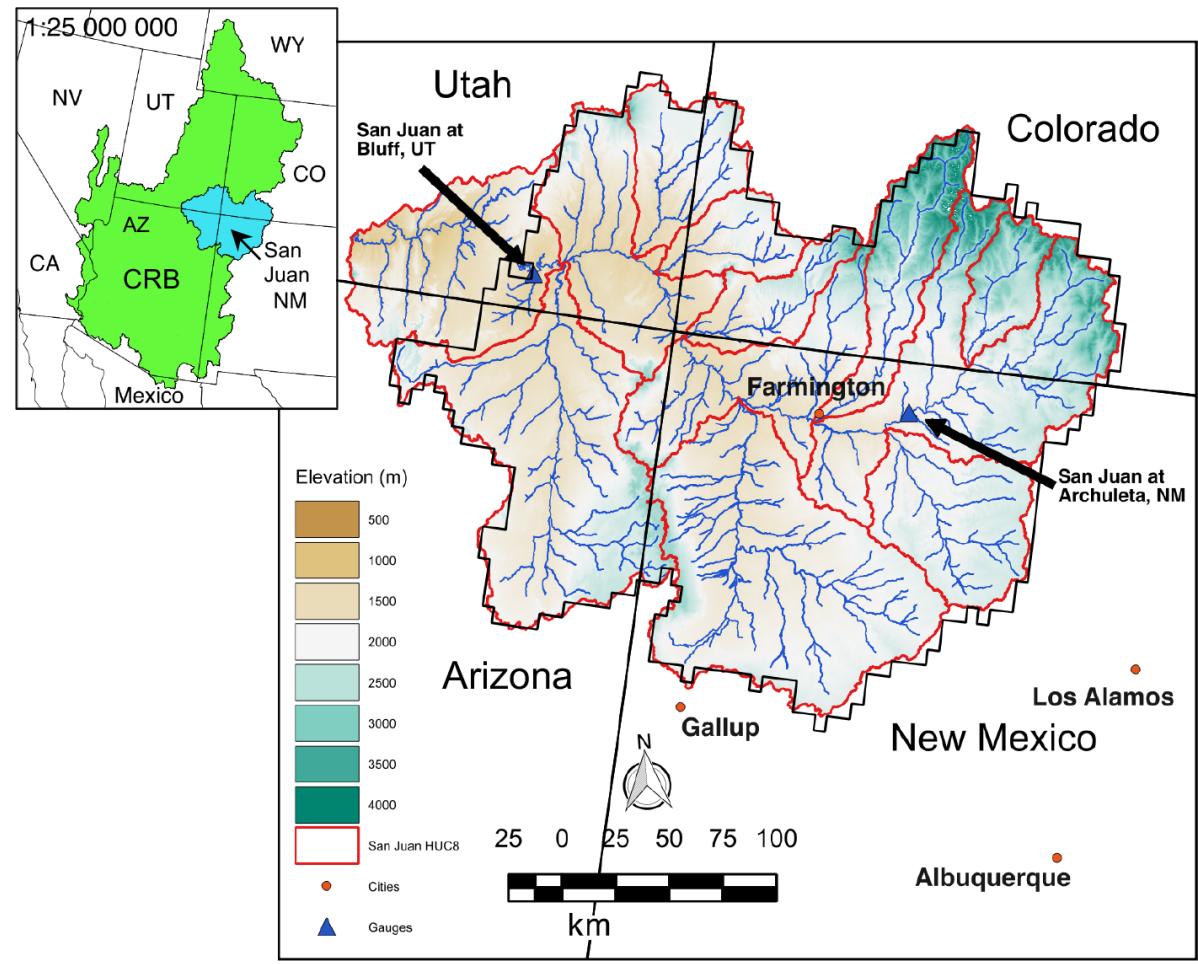

Figure 1. San Juan River basin $\left(61560 \mathrm{~km}^{2}\right)$ in the Colorado River watershed $\left(634150 \mathrm{~km}^{2}\right.$, inset), one of the most important water resources in the western USA. The San Juan River basin (outline of HUC8 watersheds shown in red) spans the Four Corners region (CO, UT, AZ and NM) of the USA, and supports multiple energy and water projects. Naturalized flow gauge sites (USBR) at San Juan at Bluff, UT and San Juan at Archuleta, NM are shown with closed blue triangles.

from the normalized difference vegetation index (NDVI) and a spatially varying monthly climatology of leaf area index (LAI), albedo, and canopy fraction (Bohn and Vivoni, 2016). Historical climate data used to run VIC (daily precipitation, minimum and maximum temperature, and wind speed) were obtained from existing gridded data sets for the USA (Livneh et al., 2015a). These daily fields were disaggregated to hourly intervals within the VIC model via algorithms as described in Bohn et al. (2013), which also estimated hourly short- and long-wave radiation and humidity. Land cover fractional areas were taken from the average of the years 2001-2012 of the Moderate-Resolution Imaging Spectroradiometer (MODIS) MCD12Q1 Collection 5 Plant Functional Type (PFT) product of Friedl et al. (2010), using the International Geosphere-Biosphere Program (IGBP) classification. Repeating climatological seasonal cycles of vegetation parameters (LAI, canopy fraction, and albedo) were derived from the MODIS Collection 5 MOD15A2, MCD43A3, and MOD13A1 products (Myneni et al., 2002; Schaaf et al., 2002; Huete et al., 2002) over the period 2000-2012, and 
aggregated spatially over the MCD12Q1 land cover classes within each $1 / 16^{\circ}$ grid cell.

Soil physical properties (e.g., bulk density, saturated hydraulic conductivity, quartz content) were derived from global data sets such as the United Nations Food and Agriculture Organization (FAO) Digital Soil Map of the World (FAO, 1998). Vegetation structural parameters, such as stomatal and canopy resistances, were taken from Ducoudré et al. (1993). Several other parameters were calibrated empirically: $D_{2}$ and $D_{3}$ (the thicknesses of the 2 nd and 3 rd soil layers); $b_{\text {infilt }}$ (the infiltration capacity curve shape parameter); $D_{\mathrm{s}}, W_{\mathrm{s}}$, and $D_{\mathrm{s}_{\max }}$ (non-linear baseflow parameters); and $\alpha_{\text {snow }}$ (the albedo of newly fallen snow). The model was calibrated using an automatic calibration tool (Yapo et al., 1998) to correct streamflow biases against the USA Bureau of Reclamation (USBR) naturalized gauged monthly streamflow (2006-2010) for the San Juan River basin at Bluff, UT (Fig. 1; Table 1). Our calibration achieved a Nash-Sutcliffe efficiency of 0.76 over the calibration period and 0.60 over the validation period for the San Juan at Bluff, UT, USBR monthly naturalized flow data (Table 1).

\subsection{Climate and vegetation change scenarios}

Our study focused on three vegetation projections and four climate projections for a total of 12 different scenarios (Fig. 2). The four climate projections employed to drive VIC were based on ESM simulations from CMIP5 (Taylor et al., 2012) climate data including daily temperature, precipitation, and wind speed, downscaled using the multivariate adaptive constructed analogue (MACA) approach (Fig. 2a and b; Abatzoglou and Brown, 2012) and again disaggregated to hourly intervals via the algorithms described in Bohn et al. (2013). We selected the four ESMs from CMIP5 because they implemented dynamic vegetation processes: HadGEM2-ES (Collins et al., 2011; Cox, 2001), MIROCESM (SIEB-DGVM; Watanabe et al., 2011; Sato et al., 2007), MPI-ESM-LR (JSBACH; Giorgetta et al., 2013; Reick et al., 2013), and IPSL-CM5B-LR (ORCHIDEE; Krinner et al., 2005). We used the representative concentration pathway (RCP) 8.5 emissions scenario, which stipulates strongly increasing emissions by 2100 (Van Vuuren et al., 2011) and corroborates current emissions on par with RCP 8.5 (Le Quéré et al., 2015).

The three vegetation projections used in this study are: (1) climate-only, which assumes static land cover (i.e., vegetation types do not change); (2) dynamic, which uses the dynamic vegetation changes present within the four CMIP5 ESMs (Fig. 2c); and (3) disturbed, which uses disturbance projections based on empirical statistical estimates of forest mortality in the southwest USA (Fig. 2d; McDowell et al., 2016). Vegetation classes were aggregated to six dominant cover types from 16 classes in the IGBP vegetation classification and from 9-13 classes in the ESMs (Table 2). Vegetation changes observed in the dynamic and disturbed scenarios were applied to the historical MODIS vegetation to alter forest coverage for future runs using a simple deltachange approach. For both the dynamic and disturbed scenarios, historical forest cover fractions were reduced and concordantly replaced by shrubs in increments of $\sim 10$ years (2006-2010, 2010-2020, and so forth); we then ran the projections in 10 year segments, with each segment having a new (constant) forest fraction and starting with the state from the previous time period. Forest cover was reduced by approximately $90 \%$ by 2100 for the disturbed scenario (McDowell and Allen, 2015; McDowell et al., 2016; Fig. 2c, d). Table 3 contains forest and shrub vegetation fractions for each scenario, and LAI, canopy fraction, and albedo for forest and shrubs used in all scenarios from the average of grid cells with greater than $50 \%$ forest cover in the San Juan River basin.

We ran the 12 different scenarios for 1950-2099. We analyzed daily, seasonal, and annual streamflow as well as monthly statistics of temperature, precipitation, evapotranspiration, and snow water equivalent (SWE) to understand changes in the water balance in the San Juan River basin. In addition, we investigated the aridity effect upon water availability under forest disturbances using a one-cell analysis. Some studies have suggested an aridity effect, whereby basins with less than $500 \mathrm{~mm}$ annual precipitation will see streamflow decrease and vice-versa (Guardiola-Claramonte et al., 2011; Adams et al., 2012), although this finding is not supported in all work (Brown et al., 2010; Caldwell et al., 2016). For the single cell, we considered climate change by adding $+3{ }^{\circ} \mathrm{C}$ (warm) and $+6^{\circ} \mathrm{C}$ (hot) to the temperature time series and changing precipitation by 20 or $-20 \%$. We then changed vegetation characteristics in the single cell to simulate changes in LAI or fractional vegetation spacing (canopy spacing).

\section{Results}

\subsection{Changing climate and land cover}

Temperature and precipitation changes are consistent with previous modeling efforts for the region (Gangopadhyay et al., 2011). The four ESMs projected consistent increases in the annual average temperature $\left(4.3-7.1^{\circ} \mathrm{C}\right.$, mean change of $5.7^{\circ} \mathrm{C}$ ) but variable changes in the annual average precipitation (both increases and decreases, -6.6-8.2\%, mean change of $1.7 \%$ ) for the San Juan River basin by comparing the last 30 years of this century to the last 30 years of the previous century (not shown). For both temperature and precipitation, changes are most dramatic and variable after the 2050s, concurrent with increasing greenhouse gas emissions. These four ESMs represent the range of warm/hot and wet/dry changes for the San Juan River basin by the 2080s in CMIP5 (Taylor et al., 2012; Brekke et al., 2013). Seasonal variations in temperature and precipitation change indicate 


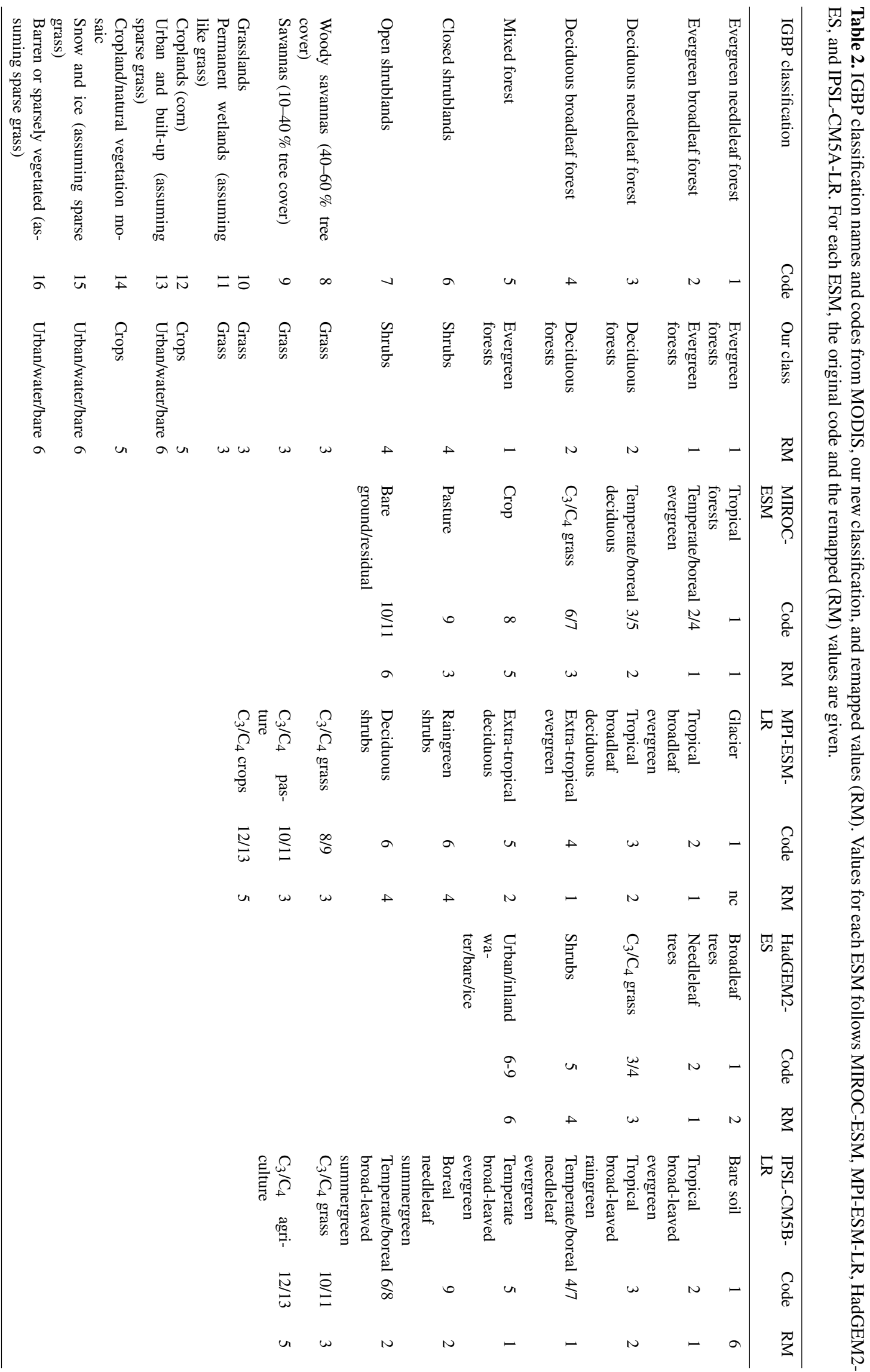



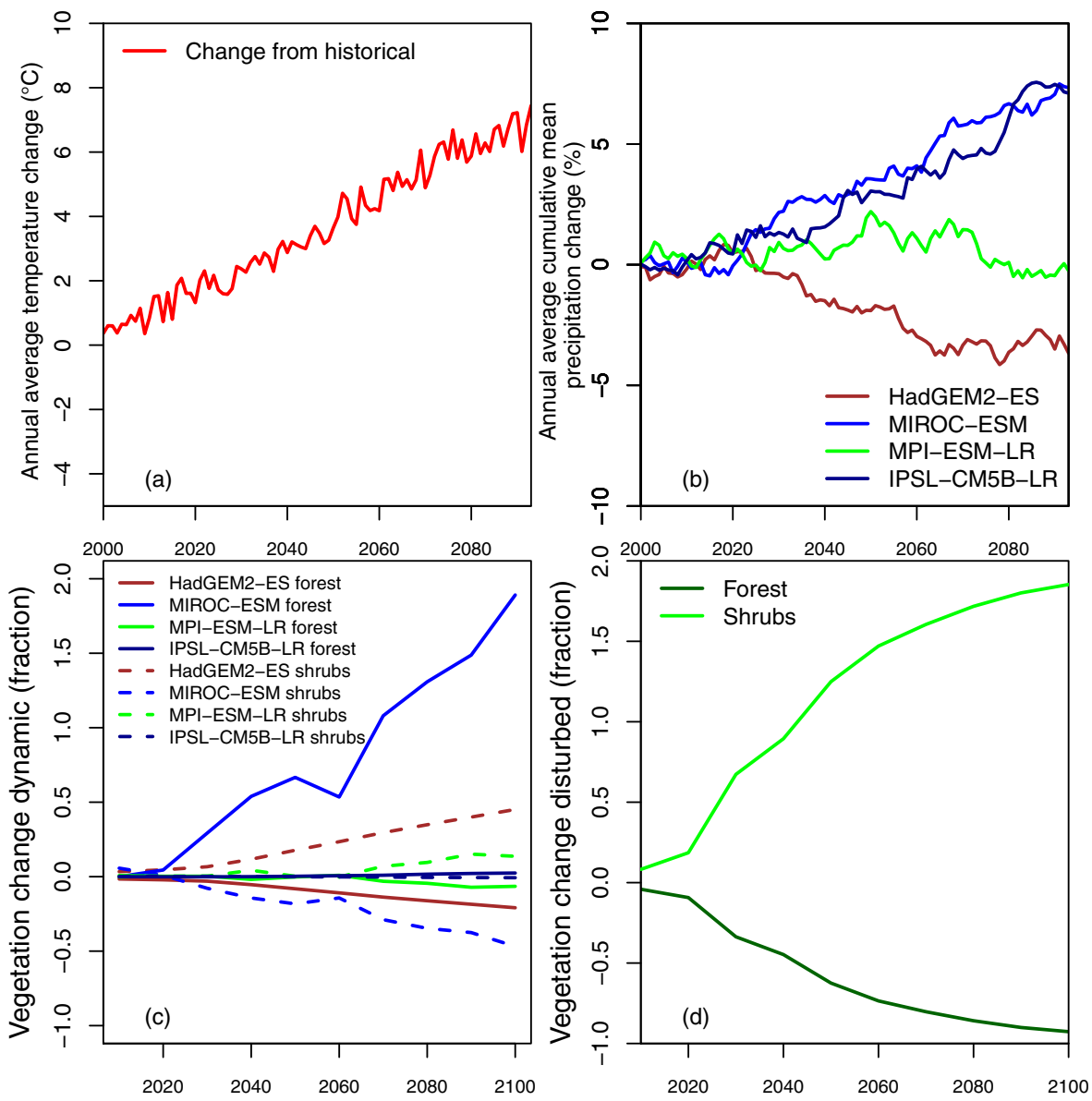

Figure 2. Temperature $\left({ }^{\circ} \mathrm{C}, \mathbf{a}\right)$, precipitation $(\%, \mathbf{b})$, and land cover (c, d) changes to the 2080s (2070-2099) averaged over the ESMs and spatially over the San Juan River basin $\left(61560 \mathrm{~km}^{2}\right.$ or 1570 grid cells). CMIP5 dynamic forest disturbances for the four ESMs as a difference from the historical climatology (1970-1999) illustrate a more moderate change with HadGEM2-ES projecting the largest decline and MIROC-ESM projecting an increase in forest cover (c). The disturbed vegetation scenario based on McDowell et al. (2016) (d) illustrates strongly declining forest covers ( $>50 \%$ forest loss) and increasing shrub covers.

important regional process shifts. For instance, summer and winter differences show that the summer is warming slightly more than the winter $\left(5.8^{\circ} \mathrm{C}\right.$ compared to $\left.5.6^{\circ} \mathrm{C}\right)$. Annual average fall and winter precipitation is projected to increase, while spring and summer precipitation is projected to decrease slightly $(-1 \%)$ with a large range in variability across the basin. We note that the signals of change for both temperature and precipitation differ from the results offered by the U.S. Department of the Interior Bureau of Reclamation data sets at $1 / 8$ th of a degree and downscaled using a slightly different technique (Bureau of Reclamation, 2011).

Our study identifies a key challenge in representing land cover: land cover change is represented differently by each of the four ESMs due to the variable representations of land use and the application of different dynamic models within each ESM (Arora, 2002). The dynamic trajectory of change is variable depending on the ESM considered (Fig. 2c). The MIROC-ESM model projects increasing forest cover, while the HadGEM2-ES model projects the most amount of change in terms of forest loss. Both IPSL-CM5B-LR and MPI-ESMLR show only a small amount of change in terms of land cover shifts by the 2080s. The disturbed scenario reflects regional changes expected in the southwestern USA (McDowell et al., 2016) and therefore projects a more severe, and likely realistic, scenario in terms of projected forest cover change in the San Juan River basin (Fig. 2d).

\subsection{Changing streamflow and water balances}

Annually, simulated streamflow in the San Juan River basin under the climate-only scenario exhibits differences of -15 to $45 \%$, while the disturbed scenario indicates a shift of -21 to $34 \%$ for the 2080 s as compared with historical streamflow, dependent on the ESM (Fig. 3). The dynamic scenario changes the streamflow by -16 to $50 \%$, but is generally very similar to the climate-only scenario. An exception to this is the MIROC-ESM dynamic scenario, which projects an in- 


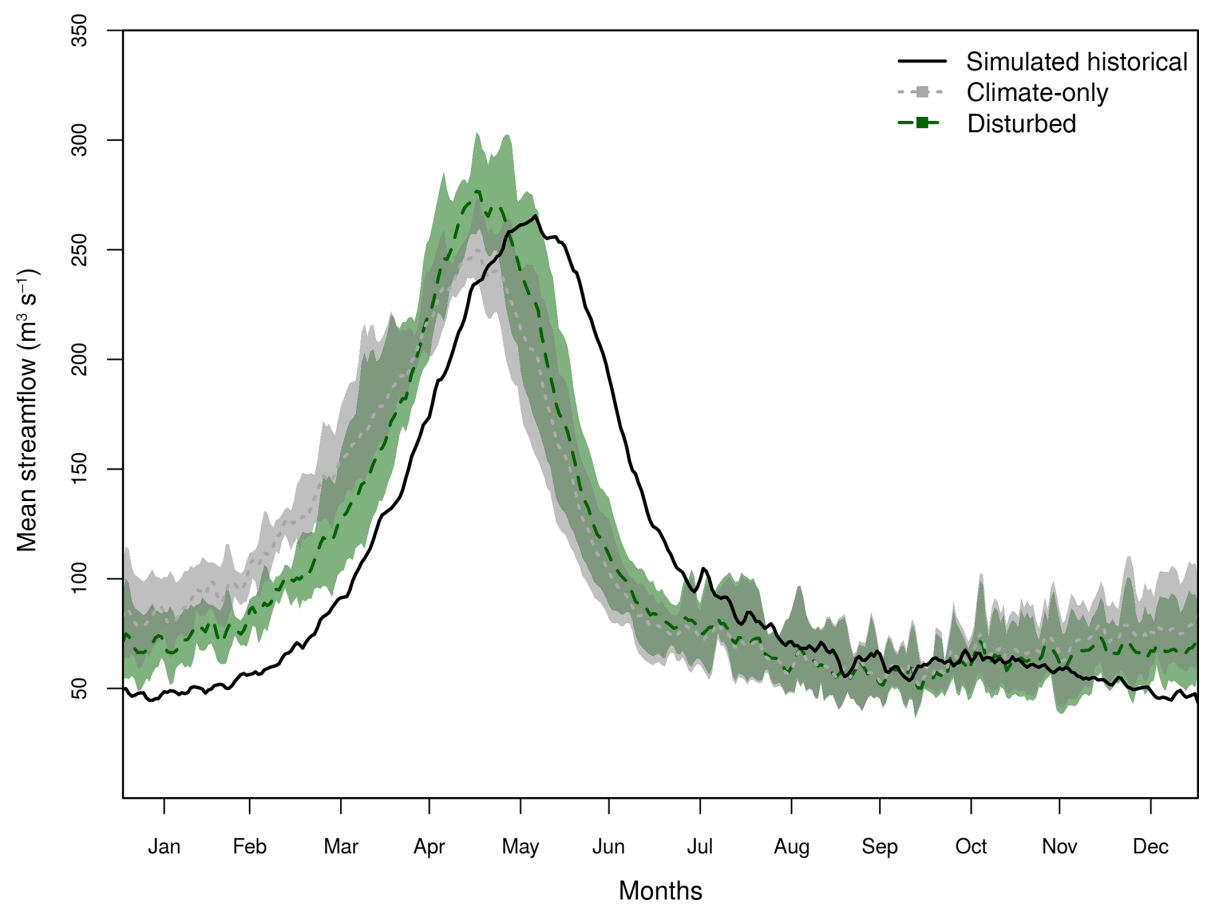

Figure 3. Monthly average future streamflows $\left(\mathrm{m}^{3} \mathrm{~s}^{-1}\right.$, 2070-2099) compared to historical (1970-1999) for the San Juan River basin at Bluff, UT. The range of responses for each ESM is represented by the semi-transparent envelope around the lines. The simulated historical streamflow is shown in black (solid line, no envelope), the climate-only scenarios are shown in grey (dashed dark grey line, grey envelope), and the disturbed scenarios are shown in green (dashed dark green line, green envelope).

crease in streamflow during winter and a decrease in summer peak flow in response to increasing forest cover and thus decreasing shrubs represented in this model (Fig. 2c). Due to the lack of a large distinction in the vegetation changes under the dynamic scenarios and resultant similarities between the climate-only and dynamic scenarios, we focus on the differences between the climate-only and the disturbed scenarios for the remainder of this paper.

Seasonal streamflow in the climate-only scenario versus historical simulated streamflow illustrates a shift in the timing of peak flow and increased winter streamflow in the San Juan River basin (Fig. 3). Peak streamflow occurs approximately 1 month earlier, owing to earlier snowmelt due to a temperature increase. This shift means that winter flows are higher and also indicates more mid-winter warming events. Under disturbed forest cover conditions, seasonal streamflow shows a different hydrograph that represents a shift in timing of winter streamflow and a change in the magnitude of both low (December-January) and high (April-May) streamflow compared to the climate-only scenario (green envelope and line, Fig. 3). The VIC simulations driven by disturbed scenarios project a lower late-fall and winter streamflow, with a delay in spring ice melt and subsequent increase in the pulse of peak streamflow during April-May. Recessional streamflow (May-July) is also slightly higher in the disturbed scenario than the climate-only scenario, resulting in greater water availability in summer (Fig. 3).
The mechanisms causing these differences in streamflow response to climate change and forest disturbance are illustrated in Fig. 4 for forest-dominant (more than $50 \%$ ) regions. In the climate-only scenario, the streamflow response is dominated by the impact of temperature on snow pack. Warmer winter temperatures and reduced March snowfall (Fig. 4a) lead to a reduction in SWE, snowmelt, and sublimation from both the pack and the canopy (Fig. 4b-e). Warmer temperatures, earlier snowmelt, and greater April rainfall subsequently lead to increases in soil evaporation (Fig. 4f) and transpiration (Fig. 4g) in the spring. Warmer temperatures also lead to increased canopy evaporation in late summer (Fig. 4h). However, the higher rates of soil evaporation and transpiration in the spring deplete the middle layer soil moisture (Fig. 4i), which diminishes their rates in the summer (Fig. 4f, g). In the fall, higher rainfall and warmer temperatures lead to greater soil evaporation but only minimal replenishment of soil moisture. Both bottom layer soil moisture (Fig. 4j) and total (surface and subsurface) runoff (Fig. 4l) exhibit earlier and smaller peaks in the spring, reflecting the earlier melting of the reduced snow pack and lower levels in summer due to greater evapotranspiration in the spring.

Two factors in the disturbed scenario further impact the snow pack, partially compensating for the effects of climate change. First, replacement of forest with shrubs leads to an increase (relative to the climate-only scenario) in the onthe-ground snow pack accumulation (Fig. 4b), a prominent 

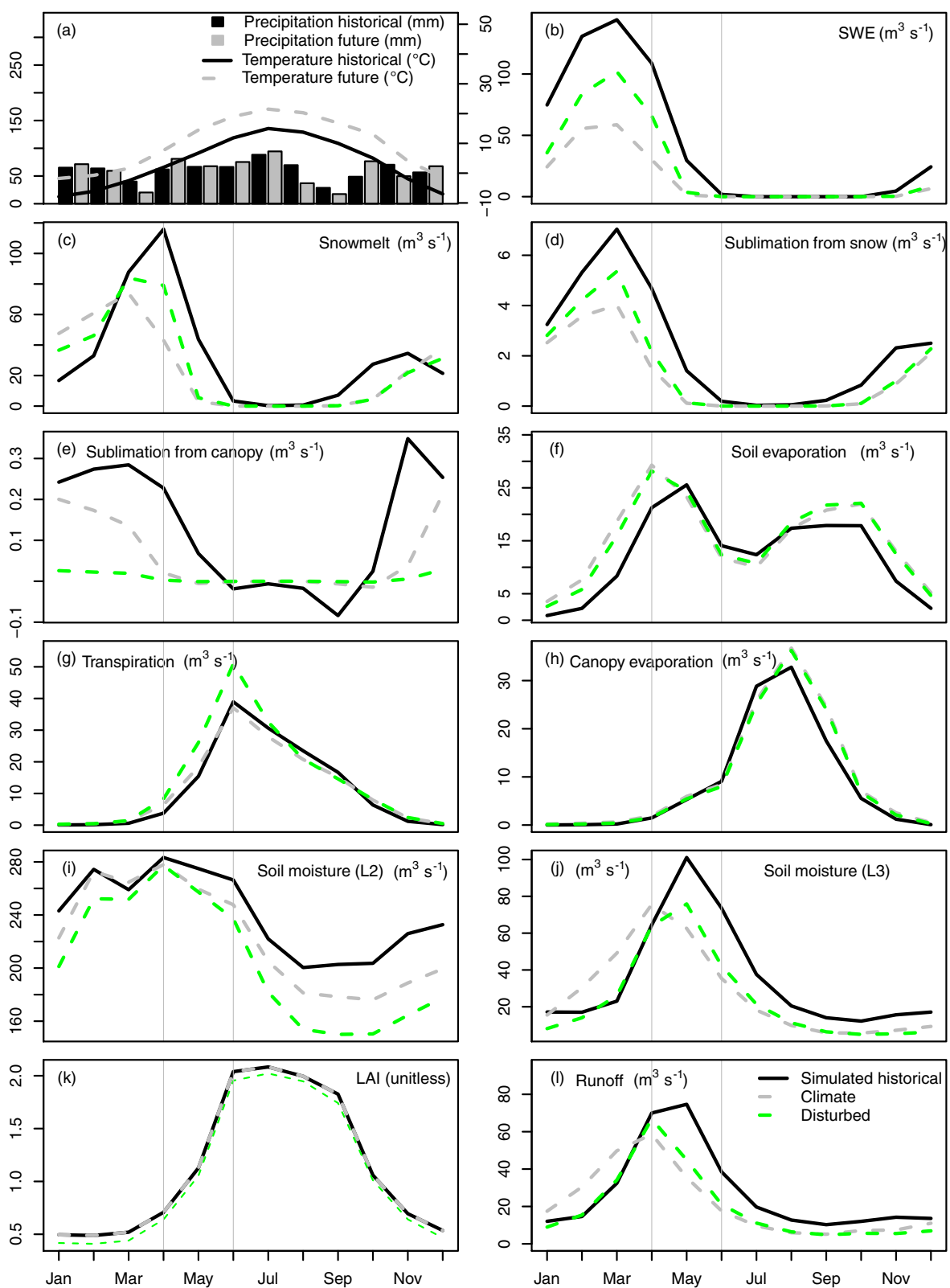

Figure 4. Monthly water balance panels for forested (greater than $50 \%$ ) regions in the San Juan River basin. Panels include precipitation $(\mathrm{mm})$ and temperature $\left({ }^{\circ} \mathrm{C}\right)$ for historical (1970-1999, black) and future (2070-2099, grey, a), snow water equivalent $\left(\mathrm{SWE}, \mathrm{m}^{3} \mathrm{~s}^{-1}, \mathbf{b}\right)$, snowmelt $\left(\mathrm{m}^{3} \mathrm{~s}^{-1}, \mathbf{c}\right)$, sublimation from snow $\left(\mathrm{m}^{3} \mathrm{~s}^{-1}, \mathbf{d}\right)$, sublimation from canopy $\left(\mathrm{m}^{3} \mathrm{~s}^{-1}, \mathbf{e}\right)$, soil evaporation $\left(\mathrm{m}^{3} \mathrm{~s}^{-1}, \mathbf{f}\right)$, transpiration $\left(\mathrm{m}^{3} \mathrm{~s}^{-1}, \mathbf{g}\right)$, canopy evaporation $\left(\mathrm{m}^{3} \mathrm{~s}^{-1}, \mathbf{h}\right)$, soil moisture from second soil later $\left(\mathrm{L} 2, \mathrm{~m}^{3} \mathrm{~s}^{-1}, \mathbf{i}\right)$, soil moisture from the third soil layer $\left(\mathrm{L} 3, \mathrm{~m}^{3} \mathrm{~s}^{-1}, \mathbf{j}\right)$, leaf area index (LAI, unitless, $\left.\mathbf{k}\right)$, and runoff $\left(\mathrm{m}^{3} \mathrm{~s}^{-1}, \mathbf{l}\right)$ for simulated historical (black line), climate-only (grey line), and disturbed scenarios (green line). The months of April and June are indicated with vertical grey lines.

feature observed in disturbed forests across North America (Boon, 2007; Zou et al., 2010; Biederman et al., 2015; Brown et al., 2014; Harpold et al., 2014). Shrubs in our VIC simulations have no canopy thus they have no mechanism to intercept snow. This disturbance-driven increase in on-the-ground snow pack partially compensates for the climate-induced streamflow increase during this time of the year. In addition, the larger on-the-ground snow pack and smaller canopy snow pack are accompanied by proportionally higher and lower rates of sublimation from the ground and canopy snow packs, respectively, relative to climate-only (Fig. 4d, e). Second, the increase in snow on the ground caused by the higher shrub coverage leads to higher rates of snowmelt (approximately $30 \%$, Fig. 4c), releasing water during the late spring and early summer (April-June; Fig. 41). The larger snowmelt flux leads to substantial increases in transpiration in spring and 


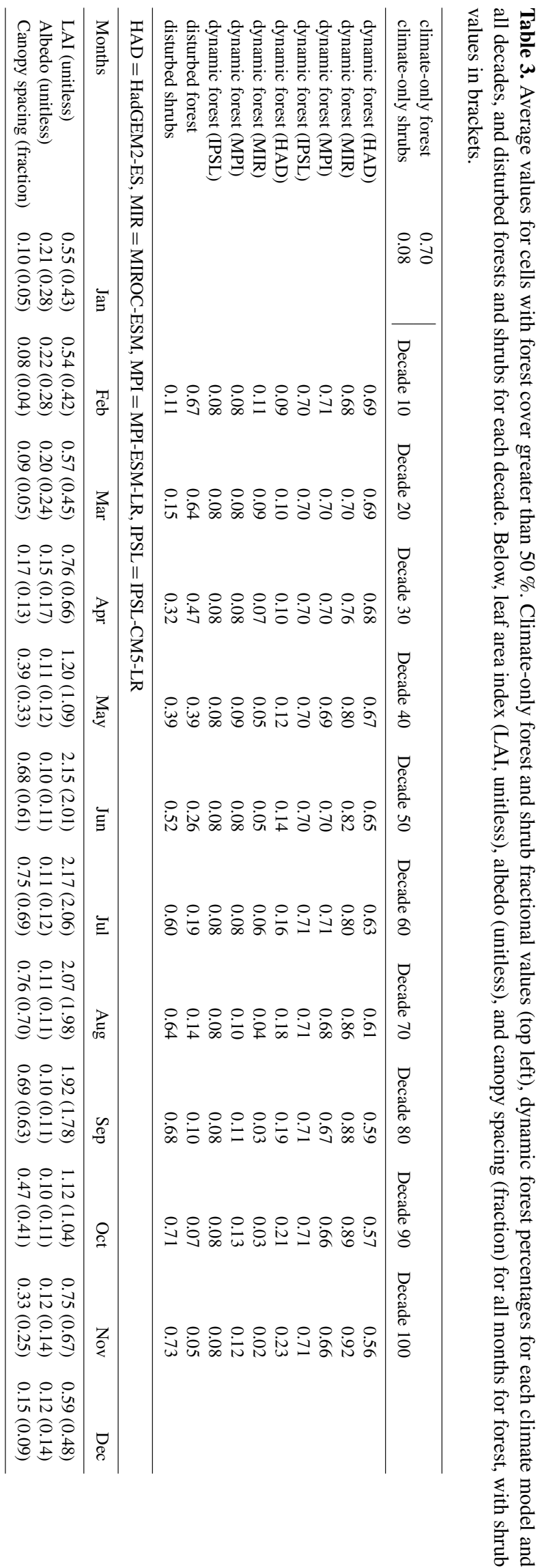

early summer, not only relative to the climate-only scenario but also relative to historical conditions (Fig. 4g). A similar increase in soil evaporation (Fig. 4f) does not occur due to the upper and middle soil layers already being saturated in the spring in the climate-only case (Fig. 4i). The high shrub transpiration rate in the disturbed scenario delays the larger snowmelt flux in reaching the bottom soil layer (Fig. 4j), leading to a delayed peak in runoff (Fig. 4j, l). Meanwhile, LAI values are similar between shrubs and forests (Fig. 4k), indicating that the water and energy balance differences are mainly due to snow process shifts between those two land cover types.

Differences in streamflow among disturbed and climateonly scenario results are most notable at fine scales (100 to $3000 \mathrm{~km}^{2}, 72$ grid cells in the San Juan) where the forest cover dominates (more than 50\%) the land cover (Fig. 5). As basin size increases (smaller circles in Fig. 5), and forest cover becomes sparser with respect to other types of land cover (e.g., mixed forest, deciduous, shrubs and grass covers), the differences between the climate-only scenario and the disturbed scenario begin to decrease, which is corroborated by several other studies (Zhang et al., 2014; Anderegg et al., 2015). The difference between the two scenarios for the densest forest and smallest portion of the basin is approximately $20 \%$, as observed for the larger circles in Fig. 5. This dynamic occurs even under changing precipitation and temperature projections that would otherwise cause increasing or decreasing streamflow (observed in Fig. 5 color ramps that change from red to blue for precipitation and different symbols for different temperature ranges). Even as the ESMs project increasing precipitation and temperature, we see the variability in responses through the cascade of scale and land cover variability. This finding is consistent with other studies that observed that variability (forest cover composition and topography) in the area and size of forest-shrub conversion can buffer responses of streamflow or evapotranspiration shifts from climate change (Winkler et al., 2014; Harpold et al., 2014; Caldwell et al., 2016).

The dynamic between temperature, precipitation, and vegetation changes is examined in more detail by using a simple single-cell analysis where climate and vegetation is altered in a sensitivity framework. Figure 6 illustrates the single-cell changes in terms of runoff from the grid cell to investigate the aridity effect. We can see that forests and shrubs act similarly in hot/warm and dry environments, while the differences are more pronounced between forests and shrubs in wetter environments (Fig. 6a). For the vegetation changes, we see that changing forest structure (e.g., fraction of the canopy that may occur as a result of pest outbreaks) results in small shifts for forests but very large shifts for shrubs (Fig. 6b). For example, shrubs with $50 \%$ canopy spacing produce more water than the forests for the majority of runoff conditions (below the 3rd quantile, Fig. 6b). On the other hand, under high runoff conditions (above the 3rd quantile, Fig. 6b) shrubs act similarly to regularly spaced shrubs. These changes are, gen- 


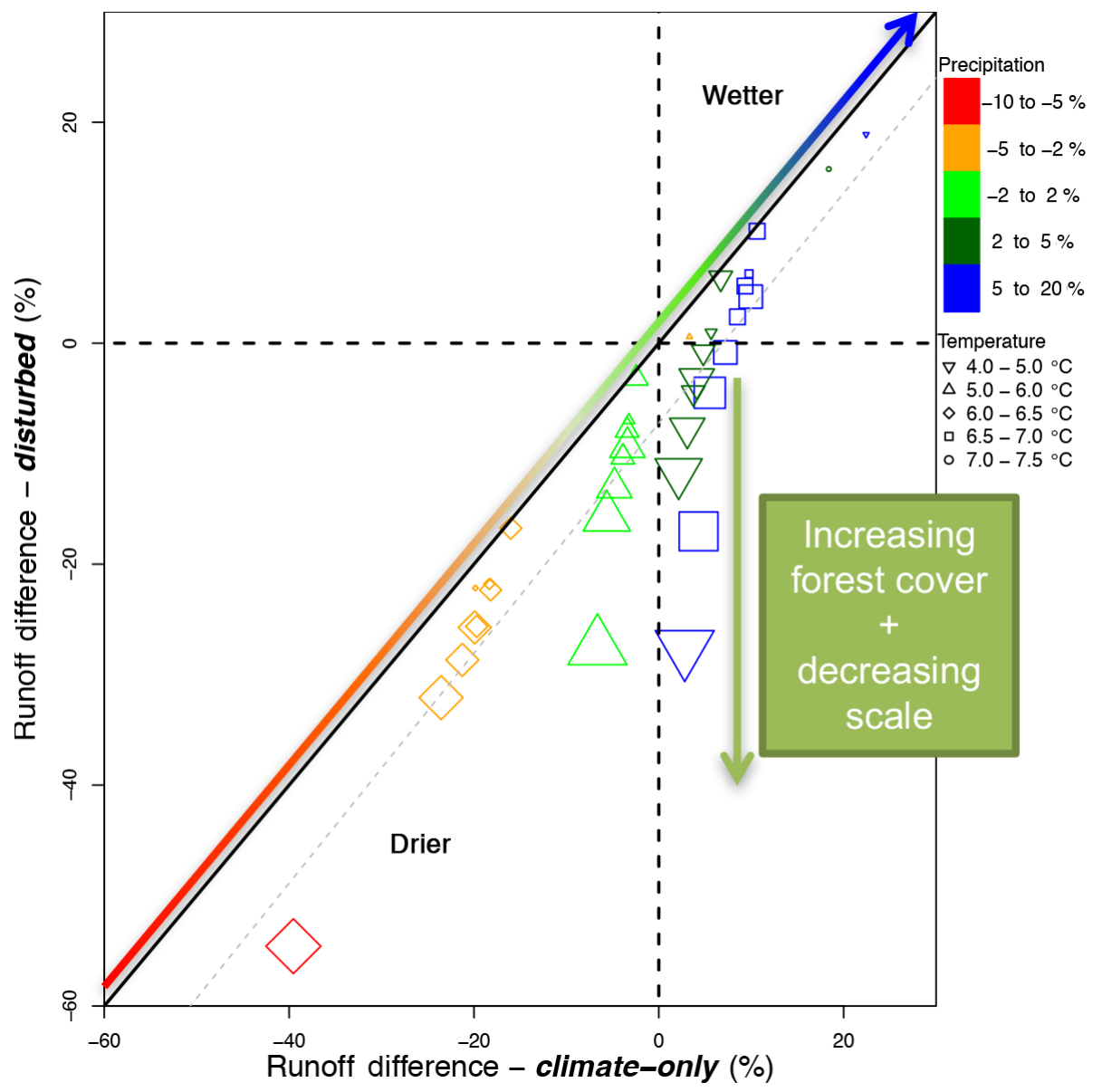

Figure 5. Runoff differences for the climate-only scenario ( $x$ axis) plotted against disturbed scenario ( $y$ axis). Increasing sizes indicate results from the entire San Juan River basin (smallest), to all forests (next largest size), and then forests with greater than 10, 50, 70, and $90 \%$ coverage (largest). All changes are shown as projected differences from the historical (in \% change).
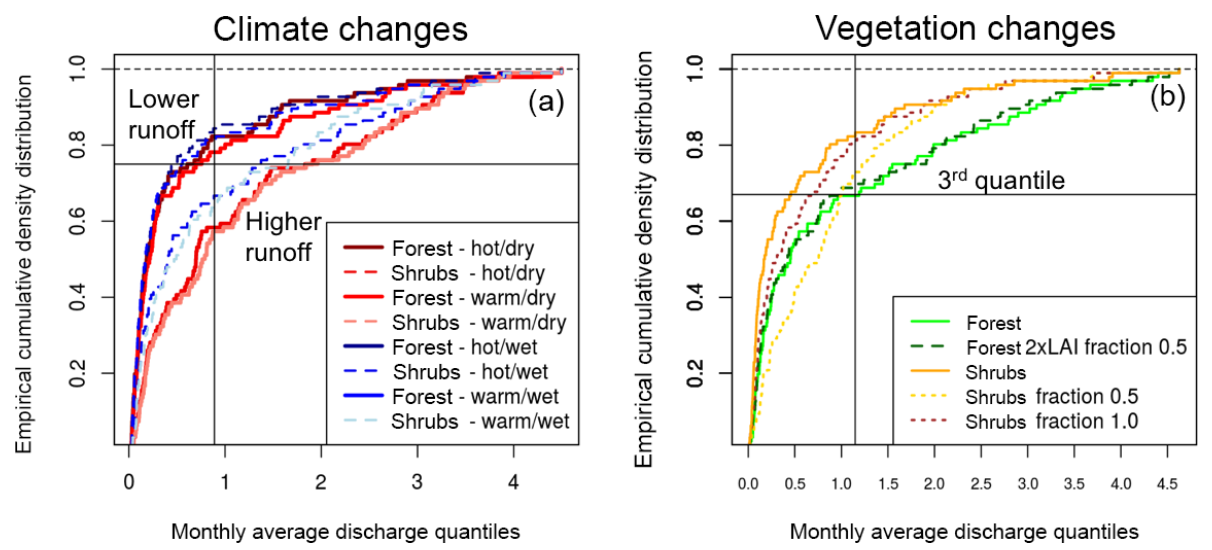

Figure 6. Cumulative density distributions are used here to illustrate the variations in (a) climate and (b) vegetation parameterizations for a single cell in the San Juan River basin. Climate alterations are shown for a hot/wet, hot/dry, warm/wet and warm/dry scenarios for both forest and shrubs. For the vegetation parameterization, forests, forests with 2 times leaf area index (LAI), shrubs, and shrubs with fractions of 0.5 and 1.0 are shown. A shrub fraction of 1 indicates that there are no spaces between the plants. The third quantile in the average of the distributions is indicated in each plot with intersecting lines. 
erally speaking, on the same order as changes within the climate. Therefore, we hypothesize that larger changes in hydrology under disturbances are more likely to occur not from the forest disturbance itself but the secondary effects such as regrowth of shrubs, the type of regrowth, and the pattern of that regrowth on the landscape. This is why timescale is such an important consideration in studies of this nature, as regrowth patterns are key to understanding how water is partitioned across a disturbed landscape.

\section{Discussion}

Climate change in the CRB is anticipated to cause large impacts to water resource sustainability (Christensen and Lettenmaier, 2007; Rasmussen et al., 2014; Dawadi and Ahmad, 2012). However, to our knowledge, few modeling studies have considered the impacts of climate change coupled with changes in vegetation (Buma and Livneh, 2015; Carroll et al., 2017; Pribulick et al., 2016). In this study, we incorporated changes from the CMIP5 dynamic vegetation models and from an estimate of forest mortality (McDowell et al., 2016) to consider the impacts of both climate and vegetation changes on the water balance in a headwater system of the CRB, the San Juan River basin. We found that failing to consider climate change coupled with vegetation disturbances could result in a $\sim 10 \%$ over-estimation of the annual water availability for this basin. For a river system such as the CRB that is already gravely stressed, $10 \%$ less water in the system may lead to significant water management challenges. Furthermore, considering seasonality in flows, the changes we illustrated in our monthly and seasonal scenarios indicate that less water will runoff during spring with more water arriving at peak melt. This could lead to water shortages and flooding, and lead to planning issues for short-term water delivery.

In this work, we considered not only the impacts of changes to streamflow but also the reasons why streamflow is changing. As in other studies, we found that at the size of the basin and the land cover variability can obscure the signal of change (Biederman et al., 2015; Penn et al., 2016). When we consider forested regions only, we are able to understand how and why streamflow is projected to change under the disturbed conditions. The main mechanism that is shifting streamflow is the manner in which shrubs impact the water balance during the cold and warm seasons. Snow pack is retained further into the melt season and when snow starts to melt, it melts more quickly and results in higher peak flows. These peak flows, however, occur during a time that the shrubs are using the water, resulting in large transpiration losses. We found differences in canopy evaporation, soil evaporation, and sublimation, but these differences are quite small overall when comparing the overall volume of water held back in the snowpack (SWE) and leaving via shrub transpiration. Overall, the differences in the mechanisms and de- livery of the water changed, and this results in a $20 \%$ reduction in the amount of water that is available for runoff through the year compared to the historical streamflow conditions for the forested regions of the San Juan River basin.

We also found that climate and disturbance have opposing influences on snow pack. In the early season, the forest disturbance partially compensates for streamflow impacts caused by warmer temperatures (Fig. 3). We see that the shift towards an earlier snowmelt is compensated in part by the fact that shrubs held on to snow for longer into the snowmelt season, releasing snow at a later date. Overall, this effect results in less water in the system and peak flows that occur at the same point in the year, but are higher in magnitude which results in lower soil moisture, such that the effect of having a late melting pack may not be beneficial for water resources. However, the snow on the ground could have important consequences for early season energy balances.

The findings presented herein represent a deviation from the more broadly accepted viewpoint that forest disturbances will lead to reduced evapotranspiration and increased streamflow. Previous findings tend to be based on studies carried out over short time periods (first $1-2$ year responses, $<5$ year studies), paired-basin analyses in watersheds disturbed by clear cuts, and where climate variability may have obscured results (Brown et al., 2005). Studies pointing towards increased streamflow also broadly found evapotranspiration from the canopy decreased, leading to an increase in runoff. However, work based on observations across scales and encompassing multiple disturbances indicates that the regrowth potential for understory, such as shrubs used in this study, is high and that the regrowth is a major controlling factor for water availability and direction of change for evapotranspiration and runoff (Caldwell et al., 2016; Biederman et al., 2014, 2015; Brown et al., 2014; Pribulick et al., 2016). Moreover, ecologists project that global forest covers are expected to decline and be replaced with species and understory compositions that are more water intensive. It is therefore paramount to treat regrowth correctly within models to align these two currently disparate principles and account accurately for changing streamflow. This is a fundamental issue because ESMs rely upon the research principles developed on plot-scale and watershed-scale observational studies and modeling work.

We also investigated the aridity effect upon water availability under forest disturbances. By comparing vegetation changes to climate shifts in a single cell, we highlighted the impacts of changing temperature and precipitation versus the impacts of changing forest cover properties. We found that the greatest differences in our results for forests and shrubs under climate change occurred under wet conditions, and vice versa for dry conditions. This may be due to the large component of water that is leaving via evaporation in arid environments. Additionally, we found that an important controlling factor for water availability in shrub environments was the canopy spacing between the shrubs that lead 
to changes in water balances and water partitioning within the environment. Thus, we believe that not only climate (i.e., aridity) but also vegetation characteristics (i.e., canopy spacing) may play a fundamental role in the impact of disturbances on water availability.

Our study did not incorporate fine-scale processes such as lateral flow, as these processes are not possible to implement using the VIC modeling approach. Suggestions from studies examining vegetation structure and patchiness illustrate that interconnected hillslope and riparian vegetation, such as shrublands, can receive water from wet upland catchment areas (Thompson et al., 2011). A recent study using the ParFlow-CLM model, which incorporates lateral flow processes, found results that are very similar to our findings (Pribulick et al., 2016). For example, Pribulick et al. (2016) show non-linear declines in streamflow in response to vegetation and temperature changes, with enhanced responses in snowmelt-driven transects and where percent vegetation change was largest. Other research suggests that when water availability declines, plants adapt and become more efficient at using water (Troch et al., 2009), which is not incorporated in the approaches undertaken in this study or Pribulick et al. (2016). Additionally, VIC model parameters that impact changes in water balances have inherent uncertainty under climate change (Bennett et al., 2017, 2012), and some of these parameters, such as canopy overstory, are represented in a binary fashion, which is not necessarily indicative of the forest and shrubland mixtures observed during forest recovery. This is a clear example of improvements that could be made to the modeling approach presented herein that should be investigated in future work.

Our study also points to the challenges associated with incorporating spatially variable estimates of changing vegetation patterns. Although CMIP5 contains information from dynamic vegetation models, we find a large disparity between the results from CMIP5 (dynamic) and the current estimates from cutting-edge research on forest cover mortality (disturbed); these methods are a scenario-style approach that do not necessary reflect future changing land cover conditions. The importance of accurately representing the effects that are observed on the catchment scale and in offline models, such as VIC, cannot be understated. ESMs require the capability to incorporate these changes in a meaningful way that can be validated using our current understanding of changes to forests in the southwestern USA and globally. This will enable the science community to accurately capture the range of responses and the impacts of changing climate and changing land cover on water resources. ESMs such as the U.S. Department of Energy's E3SM model have started down this path with the incorporation and testing of the FATES dynamic vegetation model (Fisher et al., 2015).

The differences in future streamflow projections in comparison to historical conditions we observed in this study are notable, and suggest that streamflow will decline by a minimum of $\sim 10 \%$ for headwater systems of the CRB. However, in the San Juan River basin forest cover accounts for only $17 \%$ of the area, and only $4 \%$ of these cells have greater than $80 \%$ forest cover. Impacts may be much larger for adjacent systems, such as the Gunnison, CO. Future work will investigate the impacts of changing forest cover using sensitivity analysis to understand the cumulative effect of changing climate and vegetation cover across the entire CRB.

\section{Conclusion}

The implications of declining streamflow due to forest disturbances in the San Juan River basin are significant for the CRB. Given that the San Juan basin is one of the least forested portions of the CRB and assuming similar rates of forest decline will occur nearby (Van Mantgem et al., 2009), other regions of the $\mathrm{CRB}$ are likely to experience streamflow declines of much higher severity due to changes in forest cover. Failure to adequately understand the direction and magnitude of changes could have catastrophic consequences for those who rely on this resource. The CRB - roughly $11 \%$ area of the continental USA - directly supports water supply for more than 30 million people, accounts for approximately $15 \%$ of the USA's crops and livestock (Cohen et al., 2013), and $53 \mathrm{GW}$ of power generation capacity (Buono and Eckstein, 2014; Cohen et al., 2013). Pressing work includes improvements in the spatial representation of changing forest covers across the $\mathrm{CRB}$, further investigations into drivers of change including an understanding of the role of aridity and variability, a stronger link between ecological dynamics and hydrological knowledge that is translated into models, and upward propagation of these findings into global climate models and ESMs.

Data availability. Downscaled CMIP5 climate model projections may be downloaded via the MACA web portal: https://climate. northwestknowledge.net/MACA/ (Abatzoglou, 2018). VIC model may be downloaded via GitHub: https://github.com/UW-Hydro/ VIC (Computational Hydrology Group, 2018). CMIP5 dynamic vegetation changes may be downloaded via the ESGF portal: https://esgf-node.llnl.gov/projects/esgf-1lnl/. Historical VIC forcing data may be obtained from ftp://gdo-dcp.ucllnl.org/pub/ dcp/archive/OBS/livneh2014.1_16deg/ (Livneh, 2018). Naturalized streamflow data for the Colorado River basin may be obtained from USBR: https://www.usbr.gov/lc/region/g4000/NaturalFlow/ current.html (U.S. Bureau of Reclamation, 2018). Other model parameter files and McDowell et al. (2016) vegetation disturbances may be obtained by contacting the authors.

Competing interests. The authors declare that they have no conflict of interest.

Special issue statement. This article is part of the special issue "Observations and modeling of land surface water and energy ex- 
changes across scales: special issue in Honor of Eric F. Wood”. It is a result of the Symposium in Honor of Eric F. Wood: Observations and Modeling across Scales, Princeton, New Jersey, USA, 23 June 2016.

Acknowledgements. We acknowledge the support of John Abatzaglou and Katherine Hegewisch for providing us with additional models not in the original MACA data set. We acknowledge the World Climate Research Programme's Working Group on Coupled Modeling, which is responsible for CMIP, and we thank the climate modeling groups for producing and making available their model output. For CMIP, the U.S. Department of Energy's Program for Climate Model Diagnosis and Intercomparison provides coordinating support and led development of software infrastructure in partnership with the Global Organization for Earth System Science Portals. Katrina E. Bennett, Kurt Solander, Richard S. Middleton, Nathan G. McDowell, and Chonggang Xu acknowledge the Los Alamos National Lab's LDRD program for supporting this work. Nathan G. McDowell further acknowledges support of Pacific Northwest National Laboratories LDRD program. Theodore J. Bohn was supported by grant 1216037 from the U.S. National Science Foundation (NSF) Science, Engineering and Education for Sustainability (SEES) Post-Doctoral Fellowship program and NSF grant 1462086, DMUU: Decision Center for a Desert City III: Transformational Solutions for Urban Water Sustainability Transitions in the Colorado River Basin.

Edited by: Reed Maxwell

Reviewed by: two anonymous referees

\section{References}

Abatzoglou, J. T. and Brown, T. J.: A comparison of statistical downscaling methods suited for wildfire applications, Int. J. Climatol., 32, 772-780, 2012.

Abatzoglou, J.: Multivariate Adaptive Constructed Analogs (MACA) dataset, available at: https://climate. northwestknowledge.net/MACA/, last access: 24 January 2018.

Adams, H. D., Luce, C. H., Breshears, D. D., Allen, C. D., Weiler, M., Hale, V. C., Smith, A., and Huxman, T. E.: Ecohydrological consequences of drought- and infestation-triggered tree die-off: insights and hypotheses, Ecohydrology, 5, 145-159, 2012.

Allen, C. D., Macalady, A. K., Chenchouni, H., Bachelet, D., McDowell, N., Vennetier, M., Kitzberger, T., Rigling, A., Breshears, D. D., and Hogg, E. T.: A global overview of drought and heatinduced tree mortality reveals emerging climate change risks for forests, Forest Ecol. Manage., 259, 660-684, 2010.

Allen, C. D., Breshears, D. D., and McDowell, N. G.: On underestimation of global vulnerability to tree mortality and forest die-off from hotter drought in the Anthropocene, Ecosphere, 6, 1-55, 2015.

Anderegg, W. R. L., Kane, J. M., and Anderegg, L. D. L.: Consequences of widespread tree mortality triggered by drought and temperature stress, Nature Clim. Change, 3, 30-36, 2013.

Anderegg, W. R. L., Hicke, J. A., Fisher, R. A., Allen, C. D., Aukema, J., Bentz, B., Hood, S., Lichstein, J. W., Macal- ady, A. K., McDowell, N., Pan, Y., Raffa, K., Sala, A., Shaw, J. D., Stephenson, N. L., Tague, C., and Zeppel, M.: Tree mortality from drought, insects, and their interactions in a changing climate, New Phytologist, 208, 674-683, https://doi.org/10.1111/nph.13477, 2015.

Anderson, H. W., Hoover, M. D., and Reinhart, K. G.: Forests and water: effects of forest management on floods, sedimentation, and water supply. General Technical Report PSW-018, USDA Forest Service Berkeley CA, 115, 1976.

Arora, V.: Modeling vegetation as a dynamic component in soilvegetation-atmosphere transfer schemes and hydrological models, Rev. Geophys., 40, 3-1-3-26, 2002.

Atchley, A. L., Kinoshita, A. M., Lopez, S., Trader, L., and Middleton, R. S.: Simulating surface and subsurface water balance changes due to fire severity at the hillslope scale, J. Hydrol., in review, 2018.

Bearup, L. A., Maxwell, R. M., Clow, D. W., and McCray, J. E.: Hydrological effects of forest transpiration loss in bark beetle-impacted watersheds, Nature Clim. Change, 4, 481-486, https://doi.org/10.1038/nclimate2198, 2014.

Bearup, L. A., Maxwell, R. M., and McCray, J. E.: Hillslope response to insect-induced land-cover change: an integrated model of end-member mixing, Ecohydrology, 9, 195-203, https://doi.org/10.1002/eco.1729, 2016.

Bennett, K. E., Werner, A. T., and Schnorbus, M.: Uncertainties in hydrologic and climate change impact analyses in headwater basins of British Columbia, J. Climate, 25, 5711-5730, https://doi.org/10.1175/JCLI-D-11-00417.1, 2012.

Bennett, K. E., Cannon, A. J., and Hinzman, L.: Historical trends and extremes in boreal Alaska river basins, J. Hydrol., 527, 590607, 2015.

Bennett, K. E., Urrego Blanco, J., Jonko, A., Bohn, T. J., Atchley, A. L., Urban, N. M., and Middleton, R. S.: Global sensitivity of simulated water balance indicators under future climate change in the Colorado Basin, Water Resour. Res., 54, published online, https://doi.org/10.1002/2017WR020471, 2017.

Bewley, D., Alila, Y., and Varhola, A.: Variability of snow water equivalent and snow energetics across a large catchment subject to Mountain Pine Beetle infestation and rapid salvage logging, J. Hydrol., 388, 464-479, 2010.

Biederman, J., Harpold, A., Gochis, D., Ewers, B., Reed, D., Papuga, S., and Brooks, P.: Increased evaporation following widespread tree mortality limits streamflow response, Water Resour. Res., 50, 5395-5409, 2014.

Biederman, J. A., Somor, A. J., Harpold, A. A., Gutmann, E. D., Breshears, D. D., Troch, P. A., Gochis, D. J., Scott, R. L., Meddens, A. J., and Brooks, P. D.: Recent tree die-off has little effect on streamflow in contrast to expected increases from historical studies, Water Resour. Res., 51, 9775-9789, 2015.

Bohn, T. J. and Vivoni, E. R.: Process-based characterization of evapotranspiration sources over the North American monsoon region, Water Resour. Res., 52, 358-384, https://doi.org/10.1002/2015WR017934, 2016.

Bohn, T. J., Livneh, B., Oyler, J. W., Running, S. W., Nijssen, B., and Lettenmaier, D. P.: Global evaluation of MTCLIM and related algorithms for forcing of ecological and hydrological models, Agric. Forest Meteorol., 176, 38-49, 2013. 
Bonan, G. B.: Forests and Climate Change: Forcings, Feedbacks, and the Climate Benefits of Forests, Science, 320, 1444-1449, https://doi.org/10.1126/science.1155121, 2008.

Boon, S.: Snow accumulation and ablation in a beetle-killed pine stand in Northern Interior British Columbia, J. Ecosyst. Manage., 8, 1-13, 2007.

Boon, S.: Snow ablation energy balance in a dead forest stand, Hydrol. Process., 23, 2600-2610, 2009.

Brekke, L., Thrasher, B. L., Maurer, E. P., and Pruitt, T.: Downscaled CMIP3 and CMIP5 Climate and Hydrology Projections: Release of Downscaled CMIP5 Climate Projections, Comparison with preceding Information, and Summary of User Needs, U.S. Department of the Interior, Bureau of Reclamation, Technical Services Center, Denver, Colorado, 47, 2013.

Brovkin, V., Boysen, L., Arora, V., Boisier, J., Cadule, P., Chini, L., Claussen, M., Friedlingstein, P., Gayler, V., and Van Den Hurk, B.: Effect of anthropogenic land-use and land-cover changes on climate and land carbon storage in CMIP5 projections for the twenty-first century, J. Climate, 26, 6859-6881, 2013a.

Brovkin, V., Boysen, L., Raddatz, T., Gayler, V., Loew, A., and Claussen, M.: Evaluation of vegetation cover and land-surface albedo in MPI-ESM CMIP5 simulations, J. Adv. Model. Earth Syst., 5, 48-57, https://doi.org/10.1029/2012MS000169, 2013 b.

Brown, A. E., Zhang, L., McMahon, T. A., Western, A. W., and Vertessy, R. A.: A review of paired catchment studies for determining changes in water yield resulting from alterations in vegetation, J. Hydrol., 310, 28-61, 2005.

Brown, M. G., Black, T. A., Nesic, Z., Foord, V. N., Spittlehouse, D. L., Fredeen, A. L., Bowler, R., Grant, N. J., Burton, P. J., and Trofymow, J.: Evapotranspiration and canopy characteristics of two lodgepole pine stands following mountain pine beetle attack, Hydrol. Process., 28, 3326-3340, 2014.

Brown, R., Derksen, C., and Wang, L.: A multi-data set analysis of variability and change in Arctic spring snow cover extent, 1967-2008, J. Geophys. Res.-Atmos., 115, D16111, https://doi.org/10.1029/2010jd013975, 2010.

Buma, B. and Livneh, B.: Potential Effects of Forest Disturbances and Management on Water Resources in a Warmer Climate, Forest Sci., 61, 895-903, 2015.

Buma, B. and Livneh, B.: Key landscape and biotic indicators of watersheds sensitivity to forest disturbance identified using remote sensing and historical hydrography data, Environ. Res. Lett., 12, 074028, 2017.

Buono, R. M. and Eckstein, G.: Minute 319: a cooperative approach to Mexico-US hydro-relations on the Colorado River, Water Int., 39, 263-276, 2014.

Bureau of Reclamation: West-Wide Climate Risk Assessments: Bias-Corrected and Spatially Downscaled Surface Water Projections. Technical Memorandum No. 86-68210-2011-01, U.S. Department of the Interior, Bureau of Reclamation, Technical Services Center, Denver, Colorado, 138, 2011.

Burles, K. and Boon, S.: Snowmelt energy balance in a burned forest plot, Crowsnest Pass, Alberta, Canada, Hydrol. Process., 25, 3012-3029, https://doi.org/10.1002/hyp.8067, 2011.

Caldwell, P. V., Miniat, C. F., Elliott, K. J., Swank, W. T., Brantley, S. T., and Laseter, S. H.: Declining water yield from forested mountain watersheds in response to climate change and forest mesophication, Glob. Change Biol., 2016.
Carroll, R. W. H., Huntington, J. L., Snyder, K. A., Niswonger, R. G., Morton, C., and Stringham, T. K.: Evaluating mountain meadow groundwater response to Pinyon-Juniper and temperature in a great basin watershed, Ecohydrology, 10, e1792, https://doi.org/10.1002/eco.1792, 2017.

Christensen, N. S. and Lettenmaier, D. P.: Effects of climate change on the hydrology and water resource of the Colorado River basin, Department of Civil and Environmental Engineering, University of Washington, Seattle, WA, 2002.

Christensen, N. S. and Lettenmaier, D. P.: A multimodel ensemble approach to assessment of climate change impacts on the hydrology and water resources of the Colorado River Basin, Hydrol Earth Syst. Sci., 11, 1417-1434, https://doi.org/10.5194/hess-111417-2007, 2007.

Cohen, M., Christian-Smith, J., and Berggren, J.: Water to supply the land: Irrigated agriculture in the Colorado River basin, Pacific Institute, Oakland, CA, 2013.

Collins, W. J., Bellouin, N., Doutriaux-Boucher, M., Gedney, N., Halloran, P., Hinton, T., Hughes, J., Jones, C. D., Joshi, M., Liddicoat, S., Martin, G., O’Connor, F., Rae, J., Senior, C., Sitch, S., Totterdell, I., Wiltshire, A., and Woodward, S.: Development and evaluation of an Earth-System model - HadGEM2, Geosci. Model Dev., 4, 1051-1075, https://doi.org/10.5194/gmd-4-10512011, 2011.

Computational Hydrology Group, Department of Civil and Environmental Engineering, University of Washington: The Variable Infiltration Capacity Model, available at: https://github.com/ UW-Hydro/VIC, last access: 24 January 2018.

Cox, P. M.: Description of the TRIFFID dynamic global vegetation model, Technical Note 24, Hadley Centre, United Kingdom Meteorological Office, Bracknell, UK, 2001.

Dale, V. H., Joyce, L. A., McNulty, S., Neilson, R. P., Ayres, M. P., Flannigan, M. D., Hanson, P. J., Irland, L. C., Lugo, A. E., Peterson, C. J., Simberloff, D., Swanson, F. J., Stocks, B. J., and Wotton, B. M.: Climate change and forest disturbances, BioScience, 51, 723-734, 2001.

Dawadi, S. and Ahmad, S.: Changing climatic conditions in the Colorado River Basin: Implications for water resources management, J. Hydrol., 430-431, 127-141, https://doi.org/10.1016/j.jhydrol.2012.02.010, 2012.

Ducoudré, N. I., Laval, K., and Perrier, A.: SECHIBA, a new set of parameterizations of the hydrologic exchanges at the landatmosphere interface within the LMD atmospheric general circulation model, J. Climate, 6, 248-273, 1993.

FAO: United Nations Food and Agriculture Organization. Digital Soil Map of the World and Derived Soil Properties, Land Water, Digital Media Ser., 1 (CD-ROM), Rome, Italy, 1998.

Fisher, R. A., Muszala, S., Verteinstein, M., Lawrence, P., Xu, C., McDowell, N. G., Knox, R. G., Koven, C., Holm, J., Rogers, B. M., Spessa, A., Lawrence, D., and Bonan, G.: Taking off the training wheels: the properties of a dynamic vegetation model without climate envelopes, CLM4.5(ED), Geosci. Model Dev., 8, 3593-3619, https://doi.org/10.5194/gmd-8-3593-2015, 2015.

Franchini, M. and Pacciani, M.: Comparative analysis of several conceptual rainfall-runoff models, J. Hydrol., 122, 161-219, 1991.

Friedl, M. A., Sulla-Menashe, D., Tan, B., Schneider, A., Ramankutty, N., Sibley, A., and Huang, X.: MODIS Collection 5 
global land cover: Algorithm refinements and characterization of new datasets, Remote Sens. Environ., 114, 168-182, 2010.

Gangopadhyay, S., Pruitt, T., Brekke, L., and Raff, D.: Hydrologic projections for the western United States, Eos, Transactions American Geophysical Union, 92, 441-442, 2011.

Giorgetta, M. A., Jungclaus, J., Reick, C. H., Legutke, S., Bader, J., Böttinger, M., Brovkin, V., Crueger, T., Esch, M., and Fieg, K.: Climate and carbon cycle changes from 1850 to 2100 in MPI-ESM simulations for the Coupled Model Intercomparison Project phase 5, J. Adv. Model. Earth Syst., 5, 572-597, 2013.

Gould, G. K., Liu, M., Barber, M. E., Cherkauer, K. A., Robichaud, P. R., and Adam, J. C.: The effects of climate change and extreme wildfire events on runoff erosion over a mountain watershed, J. Hydrol., 536, 74-91, 2016.

Guardiola-Claramonte, M., Troch, P. A., Breshears, D. D., Huxman, T. E., Switanek, M. B., Durcik, M., and Cobb, N. S.: Decreased streamflow in semi-arid basins following drought-induced tree die-off: a counter-intuitive and indirect climate impact on hydrology, J. Hydrol., 406, 225-233, 2011.

Harpold, A. A., Biederman, J. A., Condon, K., Merino, M., Korgaonkar, Y., Nan, T., Sloat, L. L., Ross, M., and Brooks, P. D.: Changes in snow accumulation and ablation following the Las Conchas Forest Fire, New Mexico, USA, Ecohydrology, 7, 440452, https://doi.org/10.1002/eco.1363, 2014.

Huete, A., Didan, K., Miura, T., Rodriguez, E. P., Gao, X., and Ferreira, L. G.: Overview of the radiometric and biophysical performance of the MODIS vegetation indices, Remote Sens. Environ., 83, 195-213, 2002.

Kang, S., Kimball, J. S., and Running, S. W.: Simulating effects of fire disturbance and climate change on boreal forest productivity and evapotranspiration, Sci. Total Environ., 362, 85-102, https://doi.org/10.1016/j.scitotenv.2005.11.014, 2006.

Krinner, G., Viovy, N., de Noblet-Ducoudré, N., Ogée, J., Polcher, J., Friedlingstein, P., Ciais, P., Sitch, S., and Prentice, I. C.: A dynamic global vegetation model for studies of the coupled atmosphere-biosphere system, Global Biogeochem. Cycles, 19, GB1015, https://doi.org/10.1029/2003GB002199, 2005.

Le Quéré, C., Moriarty, R., Andrew, R. M., Canadell, J. G., Sitch, S., Korsbakken, J. I., Friedlingstein, P., Peters, G. P., Andres, R. J., Boden, T. A., Houghton, R. A., House, J. I., Keeling, R. F., Tans, P., Arneth, A., Bakker, D. C. E., Barbero, L., Bopp, L., Chang, J., Chevallier, F., Chini, L. P., Ciais, P., Fader, M., Feely, R. A., Gkritzalis, T., Harris, I., Hauck, J., Ilyina, T., Jain, A. K., Kato, E., Kitidis, V., Klein Goldewijk, K., Koven, C., Landschützer, P., Lauvset, S. K., Lefèvre, N., Lenton, A., Lima, I. D., Metzl, N., Millero, F., Munro, D. R., Murata, A., Nabel, J. E. M. S., Nakaoka, S., Nojiri, Y., O’Brien, K., Olsen, A., Ono, T., Pérez, F. F., Pfeil, B., Pierrot, D., Poulter, B., Rehder, G., Rödenbeck, C., Saito, S., Schuster, U., Schwinger, J., Séférian, R., Steinhoff, T., Stocker, B. D., Sutton, A. J., Takahashi, T., Tilbrook, B., van der Laan-Luijkx, I. T., van der Werf, G. R., van Heuven, S., Vandemark, D., Viovy, N., Wiltshire, A., Zaehle, S., and Zeng, N.: Global Carbon Budget 2015, Earth Syst. Sci. Data, 7, 349-396, https://doi.org/10.5194/essd-7-349-2015, 2015.

Liang, X., Lettenmaier, D. P., Wood, E. F., and Burges, S. J.: A simple hydrologically based model of land surface water and energy fluxes for general circulation models, J. Geophys. Res., 99, 14415-14428, 1994.
Liang, X., Wood, E. F., and Lettenmaier, D. P.: Surface soil moisture parameterization of the VIC-2L model: Evaluation and modification, Global Planet. Change, 13, 195-206, 1996.

Livneh, B., Bohn, T. J., Pierce, D. W., Munoz-Arriola, F., Nijssen, B., Vose, R., Cayan, D. R., and Brekke, L.: A spatially comprehensive, hydrometeorological data set for Mexico, the U.S., and Southern Canada 1950-2013, Scientific Data, 2, 150042, https://doi.org/10.1038/sdata.2015.42, 2015a.

Livneh, B., Deems, J. S., Buma, B., Barsugli, J. J., Schneider, D., Molotch, N. P., Wolter, K., and Wessman, C. A.: Catchment response to bark beetle outbreak and dust-on-snow in the Colorado Rocky Mountains, J. Hydrol., 523, 196-210, https://doi.org/10.1016/j.jhydrol.2015.01.039, 2015b.

Livneh, B.: Daily gridded Hhdrometeorological data set for Mexico, the conterminous U.S., and southern Canada, ftp://gdo-dep. ucllnl.org/pub/dcp/archive/OBS/livneh2014.1_16deg/, last access: 24 January 2018.

McCabe, G. J. and Wolock, D. M.: Warming may create substantial water supply shortages in the Colorado River basin, Geophys. Res. Lett., 34, L22708, https://doi.org/10.1029/2007GL031764, 2007.

McDowell, N. G. and Allen, C. D.: Darcy's law predicts widespread forest mortality under climate warming, Nature Clim. Change, 5, 669-672, 2015.

McDowell, N. G., Beerling, D. J., Breshears, D. D., Fisher, R. A., Raffa, K. F., and Stitt, M.: The interdependence of mechanisms underlying climate-driven vegetation mortality, Trends Ecol. Evol., 26, 523-532, 2011.

McDowell, N. G., Williams, A. P., Xu, C., Pockman, W. T., Dickman, L. T., Sevanto, S., Pangle, R., Limousin, J., Plaut, J., Mackay, D. S., Ogee, J., Domec, J. C., Allen, C. D., Fisher, R. A., Jiang, X., Muss, J. D., Breshears, D. D., Rauscher, S. A., and Koven, C.: Multi-scale predictions of massive conifer mortality due to chronic temperature rise, Nature Clim. Change, 6, 295300, https://doi.org/10.1038/nclimate2873, 2016.

McDowell, N. G., Michaletz, S., Bennett, K. E., Solander, K., Xu, C., Maxwell, R. M., Allen, C. D., and Middleton, R. S.: Predicting Chronic Climate-Driven Disturbances and Their Mitigation, Trends Ecol. Evol., 33, 15-27, https://doi.org/10.1016/j.tree.2017.10.002, 2018.

Myneni, R. B., Hoffman, S., Knyazikhin, Y., Privette, J. L., Glassy, J., Tian, Y., Wang, Y., Song, X., Zhang, Y., Smith, G. R., Lotsch, A., Friedl, M., Morisette, J. T., Votava, P., Nemani, R. R., and Running, S. W.: Global products of vegetation leaf area and fraction absorbed PAR from year one of MODIS data, Remote Sens. Environ., 83, 214-231, https://doi.org/10.1016/S00344257(02)00074-3, 2002.

Nash, L. L. and Gleick, P. H.: Sensitivity of streamflow in the Colorado basin to climatic changes, J. Hydrol., 125, 221-241, 1991.

Penn, C. A., Bearup, L. A., Maxwell, R. M., and Clow, D. W.: Numerical experiments to explain multiscale hydrological responses to mountain pine beetle tree mortality in a headwater watershed, Water Resour. Res., 52, 3143-3161, https://doi.org/10.1002/2015WR018300, 2016.

Pomeroy, J. W., Parviainen, J., Hedstrom, N., and Gray, D. M.: Coupled modelling of forest snow interception and sublimation, Hydrol. Process., 12, 2317-2337, https://doi.org/10.1002/(SICI)10991085(199812)12:15<2317::AID-HYP799>3.0.CO;2-X, 1998. 
Pribulick, C. E., Foster, L. M., Bearup, L. A., Navarre-Sitchler, A. K., Williams, K. H., Carroll, R. W., and Maxwell, R. M.: Contrasting the hydrologic response due to land cover and climate change in a mountain headwaters system, Ecohydrology, 9, 1431-1438, 2016.

Pugh, E. and Gordon, E.: A conceptual model of water yield effects from beetle-induced tree death in snow-dominated lodgepole pine forests, Hydrol. Process., 27, 2048-2060, https://doi.org/10.1002/hyp.9312, 2013.

Rasmussen, R., Ikeda, K., Liu, C., Gochis, D., Clark, M., Dai, A., Gutmann, E., Dudhia, J., Chen, F., and Barlage, M.: Climate change impacts on the water balance of the Colorado Headwaters: High-resolution regional climate model simulations, J. Hydrometeor., 15, 1091-1116, 2014.

Reick, C., Raddatz, T., Brovkin, V., and Gayler, V.: Representation of natural and anthropogenic land cover change in MPI-ESM, J. Adv. Model. Earth Syst., 5, 459-482, 2013.

Rother, M. T., Veblen, T. T., and Furman, L. G.: A field experiment informs expected patterns of conifer regeneration after disturbance under changing climate conditions, Can. J. Forest Res., 45, 1607-1616, 2015.

Royer, P. D., Cobb, N. S., Clifford, M. J., Huang, C. Y., Breshears, D. D., Adams, H. D., and Villegas, J. C.: Extreme climatic eventtriggered overstorey vegetation loss increases understorey solar input regionally: primary and secondary ecological implications, J. Ecol., 99, 714-723, 2011.

Sato, H., Itoh, A., and Kohyama, T.: SEIB-DGVM: A new Dynamic Global Vegetation Model using a spatially explicit individual-based approach, Ecol. Model., 200, 279-307, https://doi.org/10.1016/j.ecolmodel.2006.09.006, 2007.

Schaaf, C. B., Gao, F., Strahler, A. H., Lucht, W., Li, X., Tsang, T., Strugnell, N. C., Zhang, X., Jin, Y., and Muller, J.-P.: First operational BRDF, albedo nadir reflectance products from MODIS, Remote Sens. Environ., 83, 135-148, 2002.

Scheller, R. M. and Mladenoff, D. J.: An ecological classification of forest landscape simulation models: tools and strategies for understanding broad-scale forested ecosystems, Landscape Ecol., 22, 491-505, 2007.

Schnorbus, M., Bennett, K. E., and Werner, A. T.: Quantifying the Water Resources Impacts of Mountain Pine Beetle and Associated Salvage Harvest Operations Across a Range of Watershed Scales: Hydrologic Modelling of the Fraser River Basin. Information Report BC-X-423, Canadian Forest Service, Pacific Forestry Centre, Victoria, 64, 2010.

Solander, K. C., Bennett, K. E., and Middleton, R. S.: Historical shifts in streamflow extremes in the Colorado River Basin, J. Hydrol.-Regional Studies, 12, 363-377, https://doi.org/10.1016/j.ejrh.2017.05.004, 2017.

Somor, A. J.: Quantifying streamflow change following bark beetle outbreak in multiple central Colorado catchments, The University of Arizona, 2010.

Taylor, K. E., Stouffer, R. J., and Meehl, G. A.: An overview of CMIP5 and the experiment design, B. Am. Meteorol. Soc., 93, 485-498, 2012.

Thompson, S. E., Harman, C. J., Troch, P. A., Brooks, P. D., and Sivapalan, M.: Spatial scale dependence of ecohydrologically mediated water balance partitioning: A synthesis framework for catchment ecohydrology, Water Resour. Res., 47, W00J03, https://doi.org/10.1029/2010WR009998, 2011.
Troch, P. A., Martinez, G. F., Pauwels, V. R. N., Durcik, M., Sivapalan, M., Harman, C., Brooks, P. D., Gupta, H., and Huxman, T.: Climate and vegetation water use efficiency at catchment scales, Hydrol. Process., 23, 2409-2414, https://doi.org/10.1002/hyp.7358, 2009.

U.S. Bureau of Reclamation: Colorado River Basin Natural Flow, 1906-2015, available at: https://www.usbr.gov/lc/region/g4000/ NaturalFlow/current.html, last access: 24 January 2018.

Van Mantgem, P. J., Stephenson, N. L., Byrne, J. C., Daniels, L. D., Franklin, J. F., Fulé, P. Z., Harmon, M. E., Larson, A. J., Smith, J. M., and Taylor, A. H.: Widespread increase of tree mortality rates in the western United States, Science, 323, 521-524, 2009.

Van Vuuren, D. P., Edmonds, J., Kainuma, M., Riahi, K., Thomson, A., Hibbard, K., Hurtt, G. C., Kram, T., Krey, V., and Lamarque, J.-F.: The representative concentration pathways: an overview, Clim. Change, 109, 5-31, 2011.

Varhola, A., Coops, N. C., Bater, C. W., Teti, P., Boon, S., and Weiler, M.: The influence of ground-and lidar-derived forest structure metrics on snow accumulation and ablation in disturbed forests, Can. J. Forest Res., 40, 812-821, 2010.

Watanabe, S., Hajima, T., Sudo, K., Nagashima, T., Takemura, T., Okajima, H., Nozawa, T., Kawase, H., Abe, M., Yokohata, T., Ise, T., Sato, H., Kato, E., Takata, K., Emori, S., and Kawamiya, M.: MIROC-ESM 2010: model description and basic results of CMIP5-20c3m experiments, Geosci. Model Dev., 4, 845-872, https://doi.org/10.5194/gmd-4-845-2011, 2011.

Williams, A. P., Allen, C. D., Macalady, A. K., Griffin, D., Woodhouse, C. A., Meko, D. M., Swetnam, T. W., Rauscher, S. A., Seager, R., and Grissino-Mayer, H. D.: Temperature as a potent driver of regional forest drought stress and tree mortality, Nature Clim. Change, 3, 292-297, 2013.

Winkler, R., Boon, S., Zimonick, B., and Baleshta, K.: Assessing the effects of post-pine beetle forest litter on snow albedo, Hydrol. Process., 24, 803-812, 2010.

Winkler, R., Boon, S., Zimonick, B., and Spittlehouse, D.: Snow accumulation and ablation response to changes in forest structure and snow surface albedo after attack by mountain pine beetle, Hydrol. Process., 28, 197-209, 2014.

Yapo, P. O., Gupta, H. V., and Sorooshian, S.: Multi-objective global optimization for hydrologic models, J. Hydrol., 204, 8397, 1998.

Zhang, L., Podlasly, C., Ren, Y., Feger, K.-H., Wang, Y., and Schwärzel, K.: Separating the effects of changes in land management and climatic conditions on long-term streamflow trends analyzed for a small catchment in the Loess Plateau region, NW China, Hydrol. Process., 28, 1284-1293, https://doi.org/10.1002/hyp.9663, 2014.

Zou, C. B., Ffolliott, P. F., and Wine, M.: Streamflow responses to vegetation manipulations along a gradient of precipitation in the Colorado River Basin, Forest Ecol. Manage., 259, 1268-1276, 2010. 